\title{
The Correlation Between Obesity and the Decayed, Missing, Filled Teeth (DMFT/dmft) Index
}

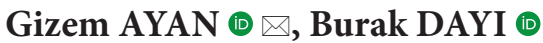 \\ Inonu University, Faculty of Dentistry, Department of Restorative Dentistry, Malatya, Turkey \\ Cite this article as: Ayan G, Dayı B. The Correlation Between Obesity and the Decayed, Missing, Filled Teeth (DMFT/dmft) Index. Turk J Diab Obes 2021;1: 96-100.
}

\begin{abstract}
Obesity is a chronic disease that significantly increases the rates of morbidity and mortality induced by the imbalance between energy intake into the body and spent energy. The prevalence of obesity rapidly increases in Turkey, as in the world. Obesity is associated with a number of diseases such as cardiovascular disorders, diabetes, high blood pressure and cancers, and its comorbidities significantly decrease with moderate weight loss. Obesity also causes oral and dental diseases such as decay, xerostomia, periodontitis, tooth loss, dentin tenderness and dental erosion. Dentists should motivate individuals with obesity by informing them about oral and dental health considering the effects of obesity on oral and dental health. This review article aimed to assess the correlation between obesity and the $\mathrm{DMFT} / \mathrm{dmft}$ index based on the literature.
\end{abstract}

Keywords: Tooth decay, DMFT, Obesity, Body mass index.

\section{Obezite ile Çürük, Kayıp, Dolgulu Dişler (DMFT/dmft) İndeksi Arasındaki İlişki}

\author{
ÖZ
}

Obezite vücuda alınan enerjiyle harcanan enerji arasındaki dengesizlikten kaynaklanan morbidite ve mortalite oranını önemli ölçüde arttıran kronik bir hastalıktır. Obezite prevalansı dünyada olduğu gibi ülkemizde de hızla artmaktadır. Obezite kardiyovasküler hastalıklar, diyabet, hipertansiyon, kanserler gibi bir dizi hastalıkla ilişkili olup; orta derecede kilo kaybı ile komorbiditeleri önemli ölçüde azalmaktadır. Obezite aynı zamanda çürük, kserostomi, periodontitis, diş kaybı, dentin hassasiyeti, dental erozyon gibi ă̆ız ve diş hastalıklarına da neden olmaktadır. Diş hekimlerinin obezitenin ağız ve diş sağlığı üzerine olan etkilerini göz önünde bulundurarak obez bireyleri ağız ve diş sağlığı konusunda ayrıca bilgilendirerek motive etmeleri gerekmektedir. Bu derlemede obezitenin DMFT/dmft indeksiyle ilişkisinin literatür desteğiyle değerlendirilmesi amaçlanmıştır.

Anahtar Sözcükler: Diş çürüğü, DMFT, Obezite, Vücut kitle indeksi

\section{INTRODUCTION}

Obesity is a metabolic disease defined as excess body fat compared to fat-free body mass. According to the World Health Organization (WHO) 2016 data, there are 650 million (13\%) obese adults and 1.9 billion (39\%) overweight adults in the world (1).
The body mass index (BMI), which is the most common measurement used to detect obesity, is calculated by dividing weight $(\mathrm{kg})$ by the square of height $\left(\mathrm{m}^{2}\right)(2,3)$. The obesity classification based on BMI is given in Table 1.

The main reason for the formation of obesity is shown as that the energy intake with diet is more than the energy spent. There are also various genetic, environmental and

ORCID: Gizem Ayan / 0000-0002-4581-0184, Burak Day1 / 0000-0002-5289-438X 
Table 1: Classification of obesity (4)

\begin{tabular}{lc}
\hline Classification & BMI $\left(\mathbf{k g} / \mathbf{m}^{2}\right)$ \\
\hline Underweight & $<18.5$ \\
\hline Normal & $18.5-24.9$ \\
\hline Overweight & $25-29.9$ \\
\hline Obese class 1 & $30-34.9$ \\
\hline Obese class 2 & $35-39.9$ \\
\hline Obese class 3 & $>40$ \\
\hline
\end{tabular}

psychological factors in the etiology of obesity. While improper lifestyle is held responsible for $70 \%$ of the risk of obesity, only $30 \%$ of the risk is attributed to genetic factors (5). The prevalence of obesity increases with a combination of factors such as excessive consumption of high-calorie comfort foods, insufficient physical activity and stress in today's societies.

Obesity causes various diseases such as high blood pressure, type II Diabetes Mellitus, hyperlipidemia, polycystic ovary syndrome, obstructive sleep apnea, osteoarthritis, depression and breast cancer $(6,7)$. Additionally, obesity is a significant cause of increased mortality apart from the diseases it causes. Obesity is regarded as one of the most significant risk factors for a severe or mortal course of the COVID-19 pandemic, which is seen worldwide today. Thus, it is even more important (8).

Non-surgical treatments such as diet, exercising, behavior change and drug therapy are preferred at the first stage of obesity treatment. Surgical treatment is used in the treatment of morbidly obese patients with Class 3 obesity, because other treatments are often insufficient. Achieving a $10 \%$ weight loss and maintaining this weight loss for a long time in obesity treatment is very important for the success of the treatment $(9,10)$.

Like smoking cigarettes, obesity is one of the most important risk factors for oral diseases (4). Obesity is associated with oral diseases such as periodontal disease, dental erosion, xerostomia and dentin sensitivity (11). Existing epidemiological studies show an inverse correlation between increasing BMI and current number of teeth (12).

Tooth decay is associated with bad dietary habits, while bad dietary habits are associated with obesity. Therefore, it is understood that there is a correlation between tooth decay and obesity (13). Additionally, the increased risk of both obesity and tooth decay with consumption of sweet foods and beverages also confirms this correlation. Studies in the literature have conflicting results on the presence of a positive correlation between obesity and tooth decay (14-16).
TNF- $\alpha$ is a cell signal protein taking part in systemic inflammation, and an increase in the TNF- $\alpha$ level in the gingival crevicular fluid may be one of the indicators of periodontal disease (17). In obese individuals, with increasing TNF- $\alpha$ in the gingival crevicular fluid, the risk of periodontal disease development increases, or the already existing disease may become more severe (18). The increased risk of decay and periodontal disease development in obese individuals may result in tooth loss (19). In the literature, it was reported that toothless men and women had higher waist-hip ratios and BMI values than those with teeth (20).

The Decayed, Missing and Filled Teeth (DMFT) index is the total index of decayed, missing and filled teeth of the individual. According to $\mathrm{WHO}$, this index, which is used to assess tooth decay, expresses the following: 0.1-1.1 DMFT index $=$ very low tooth decay, 1.2-2.6 DMFT $=$ low tooth decay, 2.7-4.4 DMFT = moderate tooth decay, 4.5-6.5 DMFT $=$ high tooth decay, and $>6.6$ DMFT $=$ very high tooth decay (21). The dmft index is the primary teeth version of the DMFT index (22). The decayed, missing and filled surfaces (DMFS) index is a form of the DMFT index applied to tooth surfaces, and the number of surfaces is four on the incisor and canine teeth and five on the premolar and molar teeth (23).

This review article is undertaken to assess the correlation between obesity and the DMFT index.

\section{Evaluation of the Correlation Between Obesity and the DMFT/dmft Index}

Obesity affects oral and dental health negatively by causing oral symptoms such as decay, tooth loss, xerostomia and periodontitis (11-13). The effects of obesity on decay, tooth loss and dry mouth are important in terms of assessing the relationship between obesity and the DMFT/dmft index, which is the index of decayed, missing and filled teeth.

Numerous clinical studies examining obesity and the $\mathrm{DMFT} / \mathrm{dmft}$ index have reported different results. The reason for this is factors about adult obesity and the DMFT index such as genetic, environmental and socio-economic factors, dietary habits, and oral hygiene habits (24-29). While carbohydrate-rich dietary habits are the main reason for the development of obesity and tooth decay, lack of oral hygiene, changing saliva values, genetic, socio-economic and environmental factors are common etiological factors for both diseases (30). A study conducted in Sweden with young adults found that obesity and being overweight were effective on tooth decay and dental erosion (31). Alm et al. (32) encountered more decay in overweight and obese individuals in comparison to normally weighted individuals. Consumed snacks and non-alcoholic beverages are found 
to be effective on the prevalence of obesity and tooth decay. A study conducted in Germany with 223 individuals including 1476 primary teeth and 4110 permanent teeth observed that the prevalence of decay in primary and permanent teeth increased along with BMI. High BMI, age, socio-economic factors, lack of oral hygiene and consumption of cariogenic beverages are shown as risk factors for decay (33).

A study conducted in Kuwait with underweight, normally weighted, overweight and obese children found that the number of decayed and filled teeth was inversely proportional to BMI. Accordingly, the difference between all groups was statistically significant, and the number of decayed and filled teeth decreased as BMI increased (34). Pinto et al. (35) and D'Mello et al. (36) found a correlation between BMI and tooth decay in children.

Increased risk of decays and periodontitis development may cause early loss of teeth in obese individuals (37). A study conducted in the United Kingdom with adults aged above 65 found that the risk of obesity was three times higher among those with less than 21 teeth compared to those with 21-31 teeth (12). Another study conducted in Sweden with women with BMI $<28 \mathrm{~kg} / \mathrm{m}^{2}$ (control group), BMI $28-38 \mathrm{~kg} /$ $\mathrm{m}^{2}$ (obese) and BMI $>38 \mathrm{~kg} / \mathrm{m}^{2}$ (morbidly obese) found that the number of teeth was lower in the obese and extreme obese women in comparison to the control group. A correlation was found between high BMI and number of missing teeth (38).

Şimşek (23) conducted a study with 140 (70 obese and 70 normally weighted) women aged between 20 and 40 and found that the DMFT and DMFS values of the obese women were significantly higher than those of the control group. A study conducted in France with 82 (41 obese and 41 normally weighted) individuals found a significant correlation between obesity and the DMFT index. The number of filled and missing teeth was similar in both groups while the number of decayed teeth and the DMFT score were higher in the obese group (39).

Markovic et al. (40) conducted a study with 422 (187 males and 235 females) children and adolescents aged between 6 and 18 and found that the DMFT and dmft scores of the overweight children and adolescents were higher in comparison to the normally weighted individuals. A study conducted on Mexican adolescents determined a positive correlation between obesity and the DMFT index and the decay component of the DMFT index (41).

Although studies in the literature where a positive relationship was found between obesity and the DMFT/dmft index have been in the majority, there are also studies showing a negative correlation or no correlation.
Sede and Ehizele (42) conducted a study with 156 (86 males and 70 females) patients who were divided into five groups based on their BMI and found no significant correlation between the DMFT score and BMI. Polat et al. (43) carried out a study with 43 (19 males and 24 females) healthy children with the mean age of 9.88 and 53 (18 males and 35 females) obese children with the mean age of 10.44, and they examined the DMFT index in the permanent teeth and $\mathrm{dmft}$ values in the primary teeth. Similar oral hygiene habits and DMFT and dmft scores were observed in both populations as a result of their study.

Although a cross-sectional study on 12-year-old French children found a positive relationship between the DMFT index and sugar consumption, no significant relationship was found between the DMFT index and BMI (44). Tong et al. (45) conducted a study on 64 children age 7-15 and could not determine a significant relationship between obesity and the DMFT index.

In a study which was conducted in Germany with 1290 (648 males and 642 females) primary school students, the children were grouped as underweight, normally weighted, overweight and obese based on their BMI. A study which calculated DFT and dft scores found a negative correlation between DFT and dft values and BMI (46). Creske et al. (47) carried out a study on 177 children and reported that the obese children had significantly lower DMFT index values in comparison to the control group, whereas they argued that this was related to diet and socioeconomic status.

\section{CONCLUSION}

The prevalence of obesity is increasing worldwide, and obesity is regarded as a predisposing factor for numerous diseases. The effects of obesity on oral and dental health are inevitable. Therefore, it is important to examine the effect of obesity on tooth decay, missing and filled teeth. Although a positive relationship was found in studies examining the correlation between obesity and the DMFT/dmft index in this review, it is also possible to find results where a negative correlation was found, or a significant difference could not be detected. The reason for these contradictory results is that the DMFT/dmft score may change based on many factors. The number of randomized studies conducted with international measures for evaluation of the correlation between obesity and DMFT/dmft should be increased.

In line with this information, dentists and medical doctors should know about the negative effects of obesity on oral and dental health and raise the awareness of obese patients about this issue. Medical doctors should definitely warn individuals diagnosed with obesity about their need to visit a dentist regularly. Dentists need to be aware of the differ- 
ences in the dental treatments of obese patients and take the necessary precautions on this issue. Considering the possibility of encountering obese patients more frequently in the future, dentistry clinics and hospitals should be designed and organized in a way to ease the transportation and treatments of obese individuals. Dentists, medical doctors and dietitians should be involved in a multidisciplinary study for prevention and treatment of obesity and undertake a significant role in protecting the health of obese individuals.

Acknowledgment

None.

\section{Author Contributions}

The opinion, source, writing and critical approach were the responsibility of both authors.

\section{Conflicts of Interest}

The authors declare no conflicts of interest for this study.

\section{Financial Support}

No financial support was received.

\section{Ethical Approval}

No Ethics Committee approval was necessary since no human and experimental products were used.

Peer-Review Process

Extremely peer-reviewed.

\section{REFERENCES}

1. Johnson S. Role of noninvasive ventilation in the management of obese patients. Curr Res Diabetes Obes. J 2019; 10: 1-2.

2. Kurt AK. Birinci basamakta obezite yönetimi. Klinik Tıp Aile Hekimliği. 2019; 11: 55-60.

3. NCD Risk Factor Collaboration (NCD-RisC)-Africa Working Group. Trends in obesity and diabetes across Africa from 1980 to 2014: An analysis of pooled population-based studies. Int J Epidemiol. 2017; 46: 1421-1432.

4. Ramakrishna A, Priya N, Nandini D, Madhushankari G. Obesity and oral health-a review. J Dent Pract Res. 2013; 1: 30-35.

5. Danaei G, Ding EL, Mozaffarian D, Taylor B, Rehm J, Murray CJL, Ezzati M. The preventable causes of death in the United States: Comparative risk assessment of dietary, lifestyle, and metabolic risk factors. PLoS Med. 2009; 6: e1000058.

6. Upadhyay J, Farr O, Perakakis N, Ghaly W, Mantzoros C. Obesity as a disease. Med Clin. 2018; 102: 13-33.

7. Cowley MA, Brown WA, Considine RV. Obesity: The problem and its management. Endocrinology: Adult \& Pediatric. Elsevier. 2016; 468-478.
8. Rychter AM, Zawada A, Ratajczak AE, Dobrowolska A, KrelaKaźmierczak I. Should patients with obesity be more afraid of COVID-19? Obes Rev. 2020; 21: e13083.

9. Elfhag K, Rössner S. Who succeeds in maintaining weight loss? A conceptual review of factors associated with weight loss maintenance and weight regain. Obes Rev. 2005; 6: 67-85.

10. Werler MM, Louik C, Shapiro S, Mitchell AA. Prepregnant weight in relation to risk of neural tube defects. JAMA. 1996; 275: 1089-1092.

11. Suvan J, D'Aiuto F. Assessment and management of oral health in obesity. Curr Obes Rep. 2013; 2: 142-149.

12. Sheiham A, Steele J, Marcenes W, Finch S, Walls A. The relationship between oral health status and Body Mass Index among older people: A national survey of older people in Great Britain. Br Dent J. 2002; 192: 703-706.

13. Dye BA, Shenkin JD, Ogden CL, Marshall TA, Levy SM, Kanellis M. The relationship between healthful eating practices and dental caries in children aged 2-5 years in the United States, 1988-1994. J Am Dent Assoc. 2004; 135: 55-66.

14. Song IS, Han K, Ryu JJ, Park JB. Obesity is inversely related to the risks of dental caries in Korean adults. Oral Dis. 2017; 23: 1080-1086.

15. Kottayi S, Bhat S, Hegde K, Peedikayil F, Chandru T, Anil S. A cross-sectional study of the prevalence of dental caries among 12-to 15-year-old overweight schoolchildren. J Contemp Dent Pract. 2016; 17: 750-754.

16. Basha S, Mohamed RN, Swamy HS, Ramamurthy PH, Sexena V. Caries incidence among obese adolescents: A 3-year prospective study. Oral Health Prev Dent. 2017; 15: 65-71.

17. Tenkumo T, Rojas-Sánchez L, Sáenz JRV, Ogawa T, Miyashita M, Yoda N, Prymak O, Sokolova V, Sasaki K, Epple M. Reduction of inflammation in a chronic periodontitis model in rats by TNF- $\alpha$ gene silencing with a topically applied siRNA-loaded calcium phosphate paste. Acta Biomater. 2020; 105: 263-279.

18. Yaylı NZA, Tunç SK, Talmaç AC, Altatari M. Relationship between obesity and oral health. Dent Med J Rev. 2019;1:1-11.

19. Yuan JCC, Lee DJ, Afshari FS, Galang MTS, Sukotjo C. Dentistry and obesity: A review and current status in US predoctoral dental education. J Dent Educ. 2012;76:11291136.

20. Johansson I, Tidehag P, Lundberg V, Hallmans G. Dental status, diet and cardiovascular risk factors in middle-aged people in northern Sweden. Community Dent Oral Epidemiol. 1994; 22: 431-436.

21. Organization WH. Diet, nutrition, and the prevention of chronic diseases: report of a joint WHO/FAO expert consultation. WHO 2003. (Accessed March, 16, 2021, at https:// www. who. int/dietphysicalactivity/publications/ trs916/en/)

22. Kemaloğlu H, Yildirim DG, Kaya A, Önal B. İzmir ilinin Seferihisar ilçesindeki 8-12 ve 13-16 yaş aralığındaki çocuklarda çürük dağılımının değerlendirilmesi, Bölüm: 1. Atatürk Üniv Diş Hek Fak Derg. 2014; 24: 353-359. 
23. Şimşek E. Obez kadınlarda uyarılmış tükürük akış hızı ve $\mathrm{dmf}$ indeksinin değerlendirilmesi. Hacettepe Üniversitesi Sağlık Bilimleri Enstitüsü, Oral Diagnoz ve Radyoloji Doktora Tezi, Ankara 2015. (Accessed March, 16, 2021, at http:// www. openaccess. hacettepe. edu. tr: 8080/xmlui/ bitstream/handle/11655/1077/2b85b629- 0a15- 46ee- a23fb90d32731110. pdf? sequence $=1$ )

24. Al-Kandari Y. Prevalence of obesity in Kuwait and its relation to sociocultural variables. Obes Rev. 2006; 7: 147-154.

25. Pereira A, Frias A, Hasegawa C, Ramos D, Rocha A, Bonfim D. Assessment between dental caries index and body mass index among adults. Oral Health Prev Dent. 2018; 16: 563-569.

26. Alswat K, Mohamed WS, Wahab MA, Aboelil AA. The association between body mass index and dental caries: Crosssectional study. J Clin Med Res. 2016; 8: 147.

27. Ashour AA, Basha S, Enan ET, Basalem A, Qahatani AA. Association between obesity/overweight and dental caries in psychiatric patients. Ann Saudi Med. 2019; 39: 178-184.

28. Adejumo A, Ogunlade O, Ozeigbe E, Oluwadaisi A, Asafa M. Assessment of association between anthropometry and dental caries among nigerian young adults: A case control study. J Adv Med Pharm Sci. 2018; 17: 1-6.

29. Ahmadi-Motamayel F, Abdolsamadi H, Goodarzi MT, Jamshidi Z, Mahdavinezhad A. Relationship between body mass index, lipid profile and dental caries. J Islam Dental Assoc Iran. 2018; 30: 106-112.

30. Li L-W, Wong HM, McGrath CP. Longitudinal association between obesity and dental caries in adolescents. J Pediatr. 2017; 189: 149-154.

31. Isaksson H. On dental caries and dental erosion in Swedish young adults. University of Gothenburg, Institute of Odontology, Cariology Doctora Thesis, Sweden 2013. (Accessed March, 16, 2021, at https:// gupea.ub.gu.se/ bitstream/2077/34072/1/gupea_2077_34072_1.pdf)

32. Alm A, Fåhraeus C, Wendt LK, Koch G, Andersson-Gäre B, Birkhed D. Body adiposity status in teenagers and snacking habits in early childhood in relation to approximal caries at 15 years of age. Int J Paediatr Dent. 2008; 18: 189-196.

33. Tschammler C, Simon A, Brockmann K, Röbl M, Wiegand A. Erosive tooth wear and caries experience in children and adolescents with obesity. J Dent. 2019; 83: 77-86.

34. Goodson JM, Tavares M, Wang X, Niederman R, Cugini M, Hasturk H, Barake R, Alsmadi O, Al-Mutawa S, Ariga J, Soparkar P, Behbehani J, Behbehani K. Obesity and dental decay: Inference on the role of dietary sugar. PloS One. 2013; 8: e74461.
35. Pinto A, Kim S, Wadenya R, Rosenberg H. Is there an association between weight and dental caries among pediatric patients in an urban dental school? A correlation study. J Dent Educ. 2007; 71: 1435-1440.

36. D'mello G, Chia L, Hamilton SD, Thomson WM, Drummon BK. Childhood obesity and dental caries among paediatric dental clinic attenders. Int J Paediatr Dent. 2011; 21: 217-222.

37. Mathus-Vliegen E, Nikkel D, Brand H. Oral aspects of obesity. Int Dent J. 2007; 57: 249-256.

38. Forslund $\mathrm{HB}$, Lindroos AK, Blomkvist $\mathrm{K}$, Hakeberg $\mathrm{M}$, Berggren U, Jontell M, Torgerson JS. Number of teeth, body mass index, and dental anxiety in middle-aged Swedish women. Acta Odontol Scand. 2002; 60: 346-352.

39. Bailleul-Forestier I, Lopes K, Souames M, Azoguy-Levy S, Frelut ML, Boy-Lefevre ML. Caries experience in a severely obese adolescent population. Int J Paediatr Dent. 2007; 17: 358-363.

40. Markovic D, Ristic-Medic D, Vucic V, Mitrovic G, Jelena Ivosevic N, Peric T, Karadzic I. Association between being overweight and oral health in Serbian schoolchildren. Int J Paediatr Dent. 2015; 25: 409-417.

41. Loyola-Rodriguez JP, Villa-Chavez C, Patiño-Marin N, Aradillas-Garcia C, Gonzalez C, de la Cruz-Mendoza E. Association between caries, obesity and insulin resistance in Mexican adolescents. J Clin Pediatr Dent. 2011; 36: 49-54.

42. Sede M, Ehizele A. Relationship between obesity and oral diseases. Niger J Clin Pract. 2014; 17: 683-690.

43. Polat GG, Cehreli SB, Taşcilar ME, Akgün ÖM, Altun C, Özgen İT. The oral health status of healthy and obese children in a Turkish population: A cross-sectional study. Turk J Med Sci. 2012; 42: 970-976.

44. Tramini P, Molinari N, Tentscher M, Demattei C, Schulte AG. Association between caries experience and body mass index in 12-year-old French children. Caries Res. 2009; 43: 468-473.

45. Tong HJ, Rudolf MCJ, Muyombwe T, Duggal MS, Balmer R. An investigation into the dental health of children with obesity: An analysis of dental erosion and caries status. Eur Arch Paediatr Dent. 2014; 15: 203-210.

46. Willerhausen B, Blettner M, Kasaj A, Hohenfellner K. Association between body mass index and dental health in 1,290 children of elementary schools in a German city. Clin Oral Investig. 2007; 11: 195-200.

47. Creske M, Modeste N, Hopp J, Rajaram S, Cort D. How do diet and body mass index impact dental caries in Hispanic elementary school children? J Dent Hyg. 2013; 87: 38-46. 